\title{
PENGARUH STRATEGI PEMBELAJARAN DAN KEMAMPUAN BERPIKIR KREATIF TERHADAP HASIL BELAJAR MENGGAMBAR EKSPRESI
}

\author{
Hero Tambunan ${ }^{1}$ dan Efendi Napitupulu ${ }^{2}$ \\ SMA Negeri 2 Kota Pematangsiantar ${ }^{1}$ dan Universitas Negeri Medan ${ }^{2}$ \\ herotambunan@yahoo.com ${ }^{l}$ dan napitupuluefendi@gmail.com ${ }^{2}$
}

\begin{abstract}
Abstrak: Penelitian ini bertujuan untuk mengetahui pengaruh Strategi Pembelajaran Dan Kemampuan Berpikir Kreatif Terhadap Hasil Belajar Menggambar Ekspresi. Penelitian ini menggunakan metode eksperimen dengan rancangan quasi eksperiment desain faktorial $2 \times 2$. Teknik statistik inferensial digunakan untuk menguji hipotesis penelitian, dimana teknik inferensial yang digunakan adalah teknik analisa varians (ANAVA) dua jalur dengan taraf signifikan 5\%. Hasil penelitian menunjukkan bahwa: (1) siswa yang diajar dengan strategi pembelajaran berorientasi aktivitas siswa memperoleh hasil belajar menggambar ekspresi lebih tinggi dari siswa yang diajar dengan strategi pembelajaran ekspositori, diperoleh nilai $F_{\text {hitung }}=6,740>F_{\text {tabel }}=$ 3,97, (2) siswa yang memiliki kemampuan berpikir kreatif tinggi memperoleh hasil belajar menggambar ekspresi lebih tinggi dari siswa yang memiliki kemampuan berpikir kreatif rendah, diperoleh nilai $F_{\text {hitung }}=225,041>F_{\text {tabel }}=3,97$, (3) tidak terdapat interaksi antara strategi pembelajaran dan kemampuan berpikir kreatif siswa dalam memberikan pengaruh terhadap hasil belajar menggambar ekspresi, diperoleh nilai $F_{\text {hitung }}=2,174<F_{\text {tabel }}=3,97$.
\end{abstract}

Kata Kunci: strategi pembelajaran, kemampuan berpikir kreatif, menggambar ekspresi

Abstract: This study aims to determine the effect of Learning Strategy and Creative Thinking Skills Learning Outcomes Draw Against Expression. This study uses a quasi experimental design of experiment $2 \times 2$ factorial design inferential statistical technique used to test hypotheses of the study, in which the inferential technique used is the technique of analysis of variance (ANOVA) two lanes with a significance level of 5\%. The results showed that: (1) students who are taught with the activity-oriented learning strategies students learn to draw expressions obtain results higher than students taught with expository learning strategy, the value of $F c=6.740>F$ table $=3.97$, (2) students have the ability to think creatively learning outcomes draw high gain higher expression of the students who have the ability to think creatively low, the value of $F c=225.041>F$ table $=$ 3.97, (3) there is no interaction between learning strategy and creative thinking abilities of students in effect learn to draw on the results of the expression, the value of $F c=2.174<F$ table $=3.97$.

Keywords: learning strategies, creative thinking abilities, drawing expressions

\section{PENDAHULUAN}

Pendidikan seni rupa merupakan salah satu bagian dari pendidikan seni budaya yang dipelajari di SMA, dimana pendidikan seni rupa diberikan pada kelas XI. Tujuan pembelajaran seni rupa di SMA adalah untuk meningkatkan kreativitas siswa, juga mampu membuat karya visual dua dimensi dan tiga dimensi. Pendidikan seni rupa dilaksanakan dengan teori dan praktik, terdiri dari 2 semester dan setiap pertemuan alokasi waktu 90 menit.

Berdasarkan pengamatan yang dilakukan di SMA Negeri 2 Kota Pematangsiantar, strategi pembelajaran yang digunakan guru seni rupa cenderung menggunakan metode ceramah. Dengan metode ini siswa hanya memperoleh sejumlah informasi yang bersumber dari guru.
Informasi dan komunikasi satu arah ini menyebabkan siswa lebih banyak menunggu tanpa berbuat sesuatu. Guru lebih banyak berbuat tanpa memberikan kesempatan untuk mengemukakan pendapat atau pengetahuan yang dimiliki siswa berkaitan dengan informasi yang telah diperoleh dari sumber lain yang erat hubungannya dengan materi yang sedang dipelajari. Hal ini menyebabkan siswa kurang berminat dalam mengikuti pembelajaran seni rupa.

Dalam proses pembelajaran akan ditemukan masalah-masalah tersebut, yaitu sering kali ditemui seorang guru kurang memperhatikan variasi dalam memberikan materi yang akan diberikan kepada siswa, sehingga pelajaran tersebut kurang atau tidak 
mampu diserap dan siswa akan cenderung lebih cepat jenuh. Dalam peningkatan kualitas pendidikan tidak dapat terjadi sebelum peningkatan kualitas pembelajaran terlebih dahulu. Untuk itu perlu meningkatkan pengetahuan tentang merancang sebuah strategi pembelajaran agar lebih efektif, efisien dan memiliki daya tarik. Variasi di dalam pemberian materi memang sangat dibutuhkan, untuk menghindari terjadinya masalah-masalah siswa yang mengakibatkan siswa bosan atau merasa sia-sia di dalam belajar. Variasi dalam pengajaran ini dikenal dengan strategi pembelajaran. Strategi pembelajaran penting di dalam mengajar karena selain mempermudah penyampaian materi dengan baik, pemilihan strategi pembelajaran yang tepat akan berpengaruh terhadap keberhasilan proses pembelajaran.

Strategi pembelajaran ekspositori lazim digunakan oleh guru dalam proses belajarmengajar karena pelaksanaan strategi ini mudah, guru hanya menyampaikan secara lisan materi yang akan diajarkan kepada siswa. Namun strategi ini kurang tepat jika monoton digunakan dalam proses pembelajaran seni rupa, karena dalam pembelajaran materi seni rupa dibutuhkan apresiasi, pengembangan ekspresi dan keterampilan siswa dalam menuangkan ide-ide kreatif ke dalam bentuk karya seni rupa.

Kemampuan berpikir kreatif sebagai suatu potensi yang dimiliki oleh setiap siswa belum menjadi perhatian pendidik dalam upaya meningkatkan hasil belajar. Dengan kemampuan berpikir kreatif yang dimilikinya, siswa dapat meningkatkan pencapaian hasil belajarnya. Siswa yang memiliki kemampuan berpikir kreatif dapat menunjukkan hasil belajar yang sama bahkan lebih baik dari siswa yang memiliki kecerdasan intelektual. Pembelajaran menggambar ekspresi dapat merangsang kemampuan berpikir kreatif siswa yang dapat ditumbuhkan dengan memberikan berbagai pengalaman belajar dan pengkondisian lingkungan belajar yang menarik dan menyenangkan. Kemampuan berpikir kreatif siswa akan berkembang bila diberi kesempatan dan kebebasan pada siswa untuk berimajinasi, berapresiasi, berekspresi, dan berkreasi dalam interaksinya selama pembelajaran.

Menurut Bloom seperti yang ditulis Dimyati dan Mudjiono (2009:26) hasil belajar dibagi dalam tiga kawasan yaitu kognitif, afektif, psikomotor. Kawasan kognitif terdiri dari enam jenis perilaku sebagai berikut: (1) pengetahuan, mencakup kemampuan ingatan tentang hal yang dipelajari dan tersimpan dalam ingatan. Pengetahuan itu berkenaan dengan fakta, peristiwa, pengertian, kaidah, teori, prinsip, atau metode; (2) pemahaman, mencakup kemampuan menangkap arti dan makna tentang hal yang dipelajari; (3) penerapan, mencakup kemampuan menerapkan metode dan kaidah untuk menghadapi masalah yang nyata dan baru, misalnya menggunakan prinsip; (4) analisis, mencakup kemampuan merinci suatu kesatuan ke dalam bagian-bagian sehingga struktur keseluruhan dapat dipahami dengan baik. Misalnya mengurangi masalah menjadi bagian yang telah kecil; (5) sintesis, mencakup kemampuan membentuk suatu pola baru. Misalnya kemampuan menyusun suatu program kerja. (6) evaluasi, mencakup kemampuan membentuk pendapat tentang beberapa hal berdasarkan kriteria tertentu, misalnya kemampuan menilai hasil karangan.

Kawasan psikomotor terdiri dari tujuh jenis perilaku yaitu: (1) persepsi yang mencakup kemampuan memilah-milahkan halhal secara khas, dan menyadari adanya perbedaan yang khas tersebut, seperti membedakan angka 6 (enam) dan 9 (sembilan); (2) kesiapan, yang mencakup kemampuan penempatan diri dalam keadaan dimana akan terjadi suatu gerakan atau rangkaian gerakan. Kemampuan ini mencakup jasmani dan rohani, seperti posisi start lomba lari; (3) gerakan terbimbing, mencakup kemampuan melakukan gerakan sesuai contoh, atau gerakan peniruan. Misalnya menirukan gerak tari; (4) gerakan yang terbiasa, mencakup kemampuan melakukan gerakan-gerakan tanpa contoh. Misalnya melakukan lompat tinggi dengan tepat; (5) gerakan kompleks, yang mencakup kemampuan melakukan gerakan atau keterampilan yang terdiri dari banyak tahap, secara lancar, efisien, dan tepat. Misalnya bongkar pasang peralatan secara tepat; (6) penyesuaian pola gerakan, yang mencakup kemampuan mengadakan perubahan dan penyesuaian pola gerak-gerik dengan persyaratan khusus yang berlaku. Misalnya keterampilan bertanding; (7) kreativitas, mencakup kemampuan melahirkan pola gerakgerak dan desain yang baru atas dasar prakarsa sendiri. Misalnya kemampuan membuat tari kreasi baru. Kawasan yang berhubungan dengan penguasaan materi menggambar ekspresi yaitu kawasan psikomotor.

Materi pokok seni rupa secara umum meliputi aspek apresiasi seni, ekspresi, berkarya 
seni, dan penyajian seni melalui pameran karya seni. Menggambar ekspresi merupakan gambar yang dibuat secara bebas berdasar pada imajinasi, persepsi, dan penafsiran penggambar kepada objeknya. Materi menggambar ekspresi terdiri dari: pengertian menggambar ekspresi, kegunaan menggambar ekspresi, asas menggambar ekspresi, teknik dasar menggambar ekspresi, karakter ekspresi pada gambar, dan terapan gambar ekspresi pada rancangan (Sachari, 2007:60).

Tabel 1. Kompetensi Dasar dan Indikator Keberhasilan Belajar Seni Rupa dalam Pembelajaran Menggambar Ekspresi

\begin{tabular}{|c|l|l|}
\hline No & $\begin{array}{l}\text { Menggambar Ekspresi } \\
\text { Kompetensi Dasar: } \\
\text { 1. Siswa mampu mengidentifikasi keunikan gagasan, teknik, bahan, dalam karya seni rupa. } \\
\text { 2. Siswa dapat menampilkan sikap apresiatif atas keunikan gagasan dan teknik dalam karya } \\
\text { seni rupa. } \\
\text { 3. Siswa dapat merancang karya seni rupa dengan memanfaatkan teknik dan corak di } \\
\text { wilayah Nusantara. }\end{array}$ \\
\hline \multicolumn{1}{|c|}{ Materi Pokok } & \multicolumn{1}{c|}{ Indikator Keberhasilan Belajar } \\
\hline 1 & Pengertian menggambar ekspresi. & Menjelaskan menggambar ekspresi. \\
\hline 2 & Kegunaan menggambar ekspresi. & Menganalisis kegunaan menggambar ekspresi. \\
\hline 3 & Asas-asas menggambar ekspresi. & Mengklasifikasikan asas-asas menggambar ekspresi. \\
\hline 4 & Teknik dasar menggambar ekspresi. & $\begin{array}{l}\text { Mengklasifikasikan teknik dasar menggambar } \\
\text { ekspresi. }\end{array}$ \\
\hline 5 & Karakter ekspresi pada gambar. & $\begin{array}{l}\text { Menjelaskan karakter ekspresi yang terdapat dalam } \\
\text { gambar. }\end{array}$ \\
\hline 6 & $\begin{array}{l}\text { Terapan gambar ekspresi pada } \\
\text { rancangan. }\end{array}$ & $\begin{array}{l}\text { Merancang gambar ekspresi dengan memanfaatkan } \\
\text { teknik dan corak di wilayah Nusantara. }\end{array}$ \\
\hline
\end{tabular}

Secara umum strategi mempunyai arti sebagai suatu garis-garis haluan untuk bertindak atau melakukan sesuatu dalam usaha mencapai sasaran yang telah ditentukan. Dapat dikatakan bahwa strategi pembelajaran merupakan polapola umum kegiatan guru dan siswa dalam bentuk kegiatan belajar-mengajar untuk mencapai tujuan yang telah ditetapkan sebelumnya. Strategi digunakan untuk memperoleh kesuksesan dalam mencapai tujuan. Dalam dunia pendidikan, strategi diartikan sebagai a plan, method, of series of activities designed to achieves a particular educational goal, hal ini dikemukakan oleh J.R David (dikutip oleh Sanjaya, 2010:126).

Suparman (2001:167) mengemukakan "strategi pembelajaran berkenaan dengan pendekatan pengajaran dalam mengelola kegiatan pembelajaran untuk mencapai materi secara sistematis sehingga tercapai kemampuan yang diharapkan dikuasai oleh siswa secara efektif dan efisien". Lebih lanjut Kemp dan Morrison (2001:124) menjelaskan strategi pembelajaran sebagai suatu kegiatan pembelajaran yang harus dikerjakan guru dan siswa agar tujuan pembelajaran dapat dicapai secara efektif dan efisien.
Roestiyah (2008:1) menjelaskan strategi pembelajaran sebagai "suatu pengetahuan tentang cara-cara mengajar yang dipergunakan oleh guru atau instruktur sebagai teknik penyajian untuk mengajar atau menyajikan bahan pelajaran kepada siswa di dalam kelas, agar pelajaran tersebut dapat ditangkap, dipahami dan digunakan oleh siswa dengan baik". Berbagai strategi pembelajaran telah banyak diperkenalkan oleh para ahli, namun guru masih sering mengalami kesulitan dalam memilih strategi yang paling cepat dengan mata pelajaran yang akan diajarkan. Hal ini disebabkan masing-masing strategi memiliki karakteristik tertentu, selain itu kondisi dan karakteristik siswa yang beragam mengharuskan seorang guru mempunyai kemampuan yang memadai untuk menerapkan suatu strategi pembelajaran.

Dalam proses belajar-mengajar strategi pembelajaran sangat penting untuk diperhatikan. Pelaksanaan strategi mendorong keaktifan siswa dalam proses pembelajaran, maka akan terjadi peningkatan kemampuan siswa dalam menerima mata pelajaran. Penggunaan strategi pembelajaran yang tepat akan membuat siswa dapat menguasai materi 
yang diajarkan dapat ditangkap, dipahami dan digunakan oleh siswa dengan baik sehingga akan mengefektifkan dan mengefisiensikan kegiatan pelajaran yang dilaksanakan.

Dick and Carey (2005:7) mengemukakan, strategi pembelajaran menekankan komponen-komponen untuk mendorong siswa belajar termasuk kegiatan pra pembelajaran, penyajian pelajaran, partisipasi peserta didik, penilaian, dan tindak lanjut melalui kegiatan pembelajaran. Suatu strategi instruksional menjelaskan komponenkomponen umum dari suatu set bahan instruksional dan prosedur-prosedur yang akan digunakan bersama bahan-bahan tersebut untuk menghasilkan hasil belajar tertentu pada siswa. Selanjutnya Suparman (2001:167) menyatakan di dalam strategi pembelajaran terkandung empat pengertian sebagai berikut: (1) Urutan kegiatan instruksional, yaitu urutan kegiatan pengajar dalam menyampaikan isi pelajaran kepada siswa, (2) Metode instruksional, yaitu cara pengajar mengorganisasikan materi pelajaran dan siswa agar terjadi proses belajar secara efektif dan efisien, (3) Media instruksional yaitu peralatan dan bahan instruksional yang digunakan pengajar dalam kegiatan instruksional, (4) Waktu yang digunakan oleh pengajar dan siswa dalam menyelesaikan setiap langkah dalam kegiatan instruksional.

Strategi pembelajaran berorientasi aktivitas siswa (SPBAS) adalah rangkaian kegiatan pembelajaran yang menekankan kepada aktivitas siswa secara optimal untuk memperoleh hasil belajar berupa perpaduan antara aspek kognitif, afektif, dan psikomotor secara seimbang. Dalam pandangan psikologi modern belajar bukan hanya sekedar menghapal sejumlah fakta atau informasi, akan tetapi peristiwa mental dan proses berpengalaman.

Menurut Dimyati dan Mudjiono (2009:115) strategi pembelajaran dengan aktivitas siswa dapat diartikan sebagai pembelajaran yang mengarah kepada pengoptimalisasian pelibatan intelektual, emosional, fisik siswa dalam proses pembelajaran. Tujuannya untuk membelajarkan siswa bagaimana belajar memperoleh dan memproses perolehan belajarnya tentang pengetahuan, keterampilan, dan sikap. Selanjutnya Raka seperti dikutip Sanjaya (2010:136) menyatakan setiap peristiwa pembelajaran berorientasi aktivitas siswa menuntut keterlibatan intelektual-emosional siswa melalui asimilasi dan akomodasi kognitif untuk mengembangkan pengetahuan, tindakan, serta pengalaman langsung dalam rangka membentuk keterampilan (motorik), penghayatan serta internalisasi nilai-nilai dalam pembentukan sikap.

SPBAS menekankan kepada aktivitas siswa secara optimal dan menghendaki hasil belajar yang seimbang dan terpadu antara kemampuan intelektual (kognitif), sikap (afektif), dan keterampilan (psikomotor) (Sanjaya, 2010:137). Sesuai dengan tujuan SPBAS adalah untuk membantu siswa agar dapat belajar mandiri dan kreatif, sehingga ia dapat memperoleh pengetahuan, keterampilan, dan sikap yang dapat menunjang terbentuknya kepribadian yang mandiri. Secara khusus pendekatan SPBAS bertujuan: Pertama, meningkatkan kualitas pembelajaran agar lebih bermakna, artinya melalui PBAS siswa tidak hanya dituntut untuk menguasai sejumlah informasi, tetapi juga bagaimana memanfaatkan informasi itu untuk kehidupannya. Kedua, mengembangkan seluruh potensi yang dimilikinya. Artinya melalui PBAS, diharapkan tidak hanya kemampuan intelektual saja yang berkembang, tetapi seluruh pribadi siswa termasuk sikap dan mental.

Secara umum proses pembelajaran dengan mengggunakan SPBAS dapat dilakukan dengan langkah-langkah sebagai berikut :

1. Mengemukakan berbagai alternatif tujuan pembelajaran yang harus dicapai sebelum kegiatan pembelajaran dimulai. Artinya, tujuan pembelajaran tidak semata-mata ditentukan oleh guru, akan tetapi diharapkan siswa terlibat dalam menentukan dan merumuskannya.

2. Menyusun tugas-tugas belajar bersama siswa. Artinya, tugas-tugas apa yang sebaiknya dikerjakan oleh siswa untuk mencapai tujuan pembelajaran. Hal ini penting dilakukan untuk memupuk tanggung jawab siswa. Manakala siswa terlibat dalam menentukan jenis tugas dan batas akhir penyelesaiannya, siswa akan lebih bertanggung jawab untuk mengerjakannya.

3. Memberikan informasi tentang kegiatan pembelajaran yang harus dilakukan. Dengan pemberitahuan rencana pembelajaran, maka siswa akan semakin paham apa yang harus dilakukan. Hal ini mendorong siswa untuk belajar lebih aktif dan kreatif.

4. Memberikan bantuan dan pelayanan kepada siswa yang memerlukannya. Guru 
perlu menyadari bahwa siswa memiliki kemampuan yang sangat beragam.

5. Memberikan motivasi, mendorong, membimbing siswa untuk belajar melalui pengajuan pertanyaan-pertanyaan. Melalui pertanyaan-pertanyaan, guru dapat mendorong agar siswa siswa termotivasi untuk belajar, atau melalui pertanyaan pula guru dapat membimbing siswa berpikir kritis dan kreatif.

6. Membantu siswa dalam menarik kesimpulan. Dalam implementasi SPBAS, siswa tidak menyimpulkan sendiri pokok bahasan yang telah dipelajarinya. Proses dan produk serta kesimpulan apa yang dapat ditarik sebaiknya diserahkan kepada siswa. Guru berperan hanya SPE merupakan bentuk dari pendekatan pembelajaran yang berorientasi kepada guru (teacher centered approach), sebab dalam strategi ini guru memegang peran yang sangat dominan.

Nursisto (2000:33) mengemukakan bahwa "berpikir kreatif akan muncul apabila seseorang melakukan aktivitas, bukan sesuatu yang mandiri atau berdiri sendiri, atau bukanlah semata-mata kelebihan yang dimiliki seseorang, berpikir kreatif merupakan bagian dari buah usaha seseorang dan menjadi seni ketika seseorang melakukan kegiatan". Sedangkan Hamalik (2008:180) mengemukakan berpikir kreatif sebagai "suatu bentuk dari proses pemecahan masalah".

Selanjutnya Munandar (2009:19) mengemukakan bahwa berpikir kreatif merupakan "suatu gaya hidup, suatu cara dalam mempersepsi dunia, hidup kreatif berarti mengembangkan talenta yang dimiliki, belajar menggunakan kemampuan diri sendiri secara optimal, menjajaki gagasan baru, tempat-tempat baru, mengembangkan kepekaan terhadap masalah lingkungan, masalah orang lain, masalah kemanusiaan".

Defenisi kreativitas yang menekankan identifikasi potensi kreatif sehingga memungkinkan pengembangannya, menurut Rhodes seperti dikutip Munandar (2009:20) dibedakan dalam dimensi pribadi (person), proses (proces), produk (product), serta kondisi pribadi dan lingkungan yang mendorong individu menjadi kreatif (press). Konsep berpikir kreatif ini diistilahkan dengan 4P (Four $P$ 's of Creatifity) yang penilaiannya sangat bergantung pada konteks sosial budaya dan waktu.
Salah satu aspek berpikir kreatif adalah kepribadian kreatif dan sangat berhubungan dengan karakteristik orang-orang kreatif. Menurut Guilford seperti yang dikutip Munandar (2009:20-22), dimensi person sebagai kriteria kreatif identik dengan kepribadian kreatif (creative personality) meliputi bakat, pengetahuan, keterampilan, motivasi, minat, sikap, dan kualitas temperamental.

Kepribadian kreatif dapat dibedakan dalam ciri kognisi dan non kognisi. Ciri kognisi meliputi bakat, pengetahuan, dan keterampilan, sedangkan ciri non kognisi meliputi motivasi, minat, sikap, dan kualitas temperamental. Ciri kognisi sama pentingnya dengan ciri non kognisi, karena tanpa ditunjang dengan kepribadian yang sesuai maka berpikir kreatif seseorang tidak akan dapat berkembang dengan wajar. Selanjutnya Guilford (1967) menyatakan bahwa kepribadian kreatif merupakan pola keteladanan yang mengacu pada kecakapan berpikir orang-orang kreatif, yaitu: kelancaran (fluency), keluwesan (flexibility), keaslian (originality), penguraian (elaboration), dan perumusan kembali (redefinition).

Selanjutnya, Menurut Wallas seperti dikutip Munandar (2009:39) menyatakan bahwa proses kreatif berlangsung melalui empat tahap, yaitu persiapan (preparation), inkubasi (incubation), iluminasi (illumination), dan verifikasi (verivication). Tahap persiapan adalah tahap identifikasi dan pengumpulan informasi untuk memecahkan masalah. Pada tahap inkubasi, proses pemecahan masalah direnungkan sampai timbul inspirasi atau gagasan untuk memecahkan masalah. Tahap iluminasi, gagasan dimunculkan dalam langkah konkrit pemecahan masalah. Tahap verifikasi, gagasan dan strategi pemecahan masalah dievaluasi secara kritis dan dihadapkan pada realita.

Pada dasarnya proses berpikir kreatif berlangsung sangat subjektif dan personal. Walaupun proses berpikir kreatif terjadi melalui tahap-tahap tertentu, namun tidak mudah untuk menentukan pada tahapan mana proses berpikir seseorang berada. Selama proses berpikir kreatif seseorang terjadi dalam setiap tahapan proses kreatif, maka dapat dikatakan bahwa hasil proses berpikir kreatif adalah produk kreatif. Pada tahap persiapan, inkubasi, dan iluminasi proses berpikir divergen yang menonjol, maka pada tahap verifikasi proses berpikir konvergen yang menonjol. 
Hasil proses berpikir kreatif adalah produk kreatif. Produk kreatif ciri seseorang disebut kreatif atau tidak. Produk kreatif merupakan kriteria puncak untuk menilai tinggi rendahnya kreatifitas seseorang berdasarkan kebaruan dan orisinalitas serta sumbangannya secara konstruktif bagi perkembangan kebudayaan dan peradaban.

Dalam perwujudannya, kemampuan berpikir kreatif membutuhkan dorongan, baik dari dalam diri maupun dari lingkungan yang memungkinkan pengembangannya. Menurut Munandar (2009:46), berpikir kreatif dapat terwujud jika ada dorongan dan dukungan dari lingkungannya (motivasi eksternal) ataupun jika ada dorongan kuat dari dalam dirinya sendiri (motivasi internal) untuk menghasilkan sesuatu. Perkembangan berpikir kreatif sebagai hasil interaksi individu dengan lingkungannya menuntut adanya dorongan (press), baik dari dalam dirinya maupun dari lingkungannya. Aktualisasi potensi kreatif sangat dipengaruhi oleh berbagai faktor penunjang maupun penghambat, baik yang ditimbulkan dari dalam diri individu maupun lingkungannya. Pada setiap orang, peranan masing-masing faktor berbeda-beda, tinggal bagaimana mendorong potensi kreatif dan mengupayakan lingkungan yang kondusif bagi pengembangannya.

Kemampuan berpikir kreatif tidak selamanya lepas dari kesulitan yang timbul dari lingkungan, justru tantangan yang diberikan oleh lingkungan membuat orang kreatif semakin matang. Pada setiap orang ada dorongan untuk mewujudkan potensi dan mengaktualisasikan diri, dorongan untuk berkembang dan menjadi matang, serta dorongan untuk mengungkapkan dan mengaktifkan semua kapasitas dan sebagai motivasi internal kreatifnya. Sedangkan penciptaan kondisi eksternal berupa keamanan dan kebebasan psikologis berupa penerimaan individu dengan segala kelebihan dan kekurangannya, mengusahakan suasana nyaman dan tidak mengancam, serta memberikan pengertian dan penerimaan secara empati melalui sudut pandang anak memungkinkan munculnya kreatif konstruktif.

Berpikir kreatif memiliki peranan yang penting dalam kehidupan manusia. Dengan kemampuan berpikir kreatif yang dimilikinya, manusia memberi bobot dan makna dalam kehidupannya. Sedangkan menurut Semiawan (1997:80), "Berpikir kreatif dapat dibedakan menjadi berpikir kreatif personal dan berpikir kreatif kebudayaan". Berpikir kreatif personal adalah kemampuan yang dimiliki oleh siapapun sedangkan berpikir kreatif kebudayaan terekspresikan dalam suatu penemuan yang secara signifikan bermakna bagi masa depan kemanusiaan. Berpikir kreatif merupakan bagian yang tidak terpisahkan dari kehidupan setiap manusia karena berpikir kreatif berlangsung dalam setiap dimensi dan aktivitas kehidupan manusia . Manusia dengan potensi kreatif yang dimilikinya sangat saling mempengaruhi dan dipengaruhi oleh lingkungan sosial-budaya tempat mereka hidup. Manusia dan lingkungan selalu mengalami perubahan dan tidak pernah berada dalam kevakuman. Kehidupan manusia selalu berubah, perubahan yang progresif dalam kehidupan dan kebudayaan mengimplikasikan adanya berpikir kreatif, karena dengan kemampuan berpikir kreatif manusia memberi nilai, warna, corak, nuansa, maupun makna dalam kehidupan.

Identifikasi potensi kreatif, menunjukkan berbagai ciri kepribadian orang kreatif, yaitu pola keteladanan sebagai karakteristik orangorang kreatif. Menurut Guilford seperti yang dikutip Munandar (2009:40) karakteristik orang-orang kreatif dapat dibedakan dalam ciri kognisi, mengacu pada kecakapan berpikir orang-orang kreatif, yaitu kelancaran, keluwesan, keaslian; penguraian, dan perumusan kembali serta ciri non kognisi meliputi motivasi, minat, sikap, dan kualitas temperamental.

Kecakapan berpikir kreatif merupakan esensi kognitif dari berpikir kreatif, orang-orang kreatif memiliki ciri-ciri kognisi yang secara signifikan berbeda dengan orang-orang kurang kreatif sehingga dijadikan kriteria untuk mengidentifikasi orang kreatif. Namun ciri non kognisi juga sama pentingnya dengan ciri kognisi. Seseorang dengan kemampuan berpikir kreatif tinggi belum tentu secara nyata menghasilkan prestasi kreatif apabila tidak didukung motivasi dan sikap positif untuk mencapai keunggulan.

Kemampuan berpikir kreatif sebagai suatu proses berpikir kreatif lebih tampil pada berpikir intuitif-imajinatif, yaitu tipe berpikir divergen yang berusaha melihat berbagai dimensi secara beragam, bahkan bertentangan dan berusaha mencari berbagai alternatif kemungkinan jawaban terhadap suatu masalah yang dihadapi sehingga dihasilkan suatu pemikiran baru maupun karya kreatif yang bermanfaat bagi kehidupan. 
Kemampuan berpikir kreatif juga diidentifikasikan berdasarkan berbagai sikap dan kepribadian yang disampaikan orang kreatif selama berinteraksi dalam kegiatan kreatifnya. Menurut Semiawan (1997:104) kemampuan berpikir kreatif terjadi berkat "serangkaian proses interaksi antara keunikan individu dengan berbagai pengalamannya, berupa keterbakatan, toleransi untuk makna ganda, fleksibel terhadap keterbatasan konsep, memperoleh kepuasan atas evaluasinya sendiri, serta kemampuan untuk bergulir dengan berbagai ide dan konsep". Sedangkan Munandar (2009:70) mengemukakan tujuh ciri sikap, kepercayaan, dan nilai yang melekat pada orang kreatif, yaitu "terbuka terhadap pengalaman baru, luwes dalam berpikir dan bertindak, kebebasan dalam ungkapan diri, menghargai fantasi, berminat pada kegiatan kreatif, percaya pada gagasan sendiri, dan mandiri dalam memberi pertimbangan". Selanjutnya Anastasi (2007:315) dari sudut pandang psikologi, kemampuan berpikir kreatif merupakan kemampuan yang dimiliki oleh setiap orang dengan tingkat berbeda-beda sebagai ekspresi tertinggi keterbakatannya dan terintegrasi dengan kemampuan memahami, mengklasifikasi, dan mengaplikasikan aturan atau prinsip dalam sebuah pola atau urutan bentuk gambar (urutan/sekuen). Serta mengidentifikasi hubungan dalam satu pasangan gambar (analogi).

Dari berbagai tinjauan literatur, dapat dirangkum dalam sepuluh karakteristik yang umumnya melekat pada orang-orang kreatif, yaitu kepekaan, keterbukaan, kemauan, keluwesan, imajinatif, inovatif, idealis, motivasi, urutan (sekuen), dan analogi.

Tabel 2. Sintesis Karakteristik Orang-Orang Kreatif (Semiawan, Munandar, dan Anastasi)

\begin{tabular}{|c|c|c|}
\hline No & Sifat-Sifat Orang Kreatif & Ciri-Ciri Orang Kreatif \\
\hline 1 & Kepekaan & $\begin{array}{l}\text { - merasakan adanya kesenjangan dan masalah } \\
\text { - meninjau sesuatu dari sudut pandang beragam } \\
\text { - peka terhadap rangsangan } \\
\text { - merasakan kesulitan orang lain }\end{array}$ \\
\hline 2 & Keterbukaan & $\begin{array}{l}\text { - terbuka terhadap pengalaman baru, unik, dan luar biasa } \\
\text { - menghargai perbedaan pendapat } \\
\text { - bersedia menerima kritik dan saran konstruktif }\end{array}$ \\
\hline 3 & Kemauan & $\begin{array}{l}\text { - memiliki keingintahuan yang besar } \\
\text { - berminat pada kegiatan kreatif } \\
\text { - tertarik pada kegiatan yang menantang }\end{array}$ \\
\hline 4 & Keluwesan & $\begin{array}{l}\text { - luwes dalam berpikir dan bertindak } \\
\text { - dapat menerima keterbatasan konsep } \\
\text { - dapat menerima adanya makna ganda } \\
\text { - dapat bergulir dengan bermacam ide dan konsep }\end{array}$ \\
\hline 5 & Imajinatif & $\begin{array}{l}\text { - dapat mengekspresikan fantasi } \\
\text { - kaya akan ide dan konsep } \\
\text { - memiliki intuisi dalam menyelesaikan masalah }\end{array}$ \\
\hline 6 & Inovatif & $\begin{array}{l}\text { - orisinil dari tindakan dan perbuatan } \\
\text { - berani membuat kejutan dan menyimpang dari tradisi } \\
\text { - berorientasi pada masa kini dan akan datang } \\
\text { - memiliki inisiatif untuk perubahan } \\
\end{array}$ \\
\hline 7 & Idealis & $\begin{array}{l}\text { - bebas menyatakan pendapat } \\
\text { - tidak takut berbuat kesalahan } \\
\text { - tidak mudah dipengaruhi orang lain } \\
\text { - kritis terhadap keadaan }\end{array}$ \\
\hline 8 & Motivasi & $\begin{array}{l}\text { - dorongan kuat untuk mencapai keunggulan } \\
\text { - komitmen tinggi terhadap tugas } \\
\text { - tanggung jawab atas setiap tindakan } \\
\text { - tekun dan tidak cepat bosan }\end{array}$ \\
\hline 9 & Urutan (sekuen) & $\begin{array}{l}\text {-Kemampuan memahami, mengklasifikasi, } \\
\text { mengaplikasikan aturan atau prinsip dalam sebuah pola atau } \\
\text { urutan bentuk gambar }\end{array}$ \\
\hline
\end{tabular}


Menurut Semiawan (1997:65), penilaian berpikir kreatif sebagai salah satu dimensi keberbakatan, pengukurannya harus dicari di luar batas-batas intelegensi karena pengukuran terhadap berpikir kreatif tidak berkorelasi dengan intelegensi. Selanjutnya Anastasi (2007:311) menyatakan tes keterampilan kognitif (Test of Cognitif Skills : TCS) dapat digunakan untuk menguji keberbakatan dalam hal ini kemampuan berpikir kreatif yang terdiri dari klasifikasi figural/gambar, mengikuti arah, seri gambar, urutan/sekuen, hubungan ruang, penyelesaian gambar, dan analogi bentuk. Tes keterampilan kognitif dapat dikategorikan juga sebagai tes non-verbal.

Seseorang dengan kemampuan intelegensi tinggi tidak menjamin lahirnya prestasi kreatif, tetapi seseorang dengan intelegensi rendah tidak memungkinkannya untuk menjadi kreatif. Orang-orang yang memiliki kemampuan berpikir kreatif tinggi dapat menghasilkan prestasi belajar yang sama baiknya bahkan lebih baik dari orang-orang yang memiliki intelegensi tinggi.

Selain itu Munandar (2009:59) menyatakan, bahwa "tes intelegensi digunakan untuk menguji kemampuan berpikir konvergen, sedangkan tes berpikir kreatif dikembangkan untuk mengukur kemampuan berpikir divergen". Tes kemampuan berpikir kreatif berbeda dengan tes intelegensi terutama pada kriteria jawaban. Tes intelegensi mengukur kemampuan konvergen dengan jawaban benar dan salah, sedangkan tes kemampuan berpikir kreatif mengukur kemampuan berpikir divergen tanpa adanya jawaban benar atau salah, penilaiannya berdasarkan pada keunikan jawaban, perbedaan jawaban, banyaknya jawaban yang diberikan, dan keterincian jawaban.

Kemampuan berpikir kreatif sebagai suatu potensi yang dimiliki setiap siswa belajar menuntut pemahaman menyeluruh terhadap sifat kemampuan kreatif dan kondisi sekitar yang menunjang dalam upaya mengembangkan dan menerapkan strategi pembelajaran yang tepat untuk mengembangkan potensi kreatif yang dimiliki dan pencapaian hasil belajar yang lebih baik.

Kemampuan berpikir kreatif yang dimiliki siswa dalam pembelajaran dapat dibedakan tinggi-rendahnya berdasarkan ciriciri non-kognisi termasuk motivasi, sikap, maupun kepribadian kreatif. Ciri-ciri ini secara nyata dapat dilihat perbedaannya dalam kelompok siswa belajar, baik melalui pengamatan langsung berdasarkan kemampuan dan sikap belajar siswa dalam menghadapi berbagai permasalahan selama pembelajaran, maupun dengan melakukan pengukuran langsung menggunakan berbagai instrumen tes berpikir kreatif.

Derajat kemampuan berpikir kreatif siswa memberikan pengaruh terhadap efektifitas proses pembelajaran dan pencapaian hasil belajar. Penilaian pencapaian hasil belajar siswa dengan berbagai tingkat berpikir kreatif dikaitkan dengan teori belajar Gestalt yang memandang terjadinya proses belajar karena adanya tujuan, eksplorasi, imajinasi, dan kreatif, serta hasilnya sangat berhubungan dengan pengamatan, kemampuan berpikir, dan pengalaman.

Sehubungan dengan penelitian ini, identifikasi kemampuan berpikir kreatif siswa SMA Negeri 2 Pematangsiantar dalam pembelajaran penelitian ini dilakukan dengan pengukuran langsung terhadap kemampuan berpikir kreatif menggunakan tes keterampilan kognitif (test of cognitive skills), terdiri dari tes non-verbal (figural) yang dibuat dan dikembangkan Anastasi (2007:311). Tes ini menuntut kemampuan siswa belajar secara visual dalam menanggapi suatu permasalahan dari sudut pandang yang berbeda dan mencari jawabannya dengan cara-caranya sendiri. Siswa belajar dituntut untuk mampu memahami, mengklasifikasi, dan mengaplikasikan aturan atau prinsip dalam sebuah pola atau urutan bentuk gambar (urutan/sekuen). Serta mengidentifikasi hubungan dalam satu pasangan gambar yang meliputi gambar orang, binatang, tumbuhan, dan simbol grafik (analogi).

Dalam perwujudannya, berpikir kreatif siswa SMA Negeri 2 Pematangsiantar ditampilkan dalam kemampuan berpikir kreatif yang meliputi urutan/sekuen, analogi, dan berbuat untuk menyelesaikan berbagai permasalahan yang dihadapi selama pembelajaran. Dengan kemampuan berpikir kreatif yang dimilikinya, siswa belajar untuk mampu melihat dan meninjau suatu permasalahan dalam perspektif yang beragam dan berusaha mencari jawabannya dengan caracaranya sendiri, sehingga mereka terlatih memahami seni rupa secara mendalam dan menemukan 


\section{METODE}

Penelitian ini dilaksanakan di SMA Negeri 2 Kota Pematangsiantar, Kecamatan Siantar Utara. Populasi dalam penelitian ini adalah seluruh siswa kelas XI SMA Negeri 2 Kota Pematangsiantar, yang terdiri dari 6 (enam) kelas yaitu XI IA-1, XI IA-2, XI IA-3, XI IS-1, XI IS-2, dan XI IS-3 dengan jumlah keseluruhan siswa adalah 241 orang. Setiap kelas dalam populasi memiliki karakteristik yang sama, artinya setiap kelas tidak memiliki siswa yang pernah tinggal kelas, siswa rata-rata memiliki umur yang tidak jauh berbeda secara signifikan, menggunakan kurikulum pendidikan yang sama, pembagian kelas tidak dilakukan berdasar ranking, sehingga tidak terdapat kelas unggulan yang karakteristik siswanya berbeda.

Teknik pengambilan sampel dalam penelitian ini adalah teknik sampel kelompok secara acak (cluster random sampling). Untuk menentukan jenis perlakuan pada setiap sampel dilakukan undian dan hasilnya diperoleh kelas XI IA-1 (40 orang siswa) menggunakan strategi pembelajaran berorientasi aktivitas siswa dan kelas XI IS-1 (40 orang siswa) menggunakan strategi pembelajaran ekspositori, maka jumlah sampel penelitian adalah 80 orang.

Penelitian ini menggunakan metode eksperimen dengan rancangan quasi eksperiment desain faktorial $2 \times 2$. Melalui desain ini akan dibandingkan strategi pembelajaran berorientasi aktivitas siswa dan strategi pembelajaran ekspositori terhadap hasil belajar menggambar ekspresi ditinjau dari siswa. Variabel-variabel tersebut selanjutnya akan dimasukkan di dalam desain penelitian sebagai berikut :

Tabel 3. Rancangan Eksperimen Desain Faktorial 2 x 2

\begin{tabular}{|c|c|c|}
\hline Kemampuan Berpikir Kreatif & \multicolumn{2}{|c|}{ Strategi Pembelajaran $(\mathrm{S})$} \\
\cline { 2 - 3 } Siswa $(\mathrm{C})$ & Berorientasi Aktivitas Siswa $\left(\mathrm{S}_{1}\right)$ & Ekspositori $\left(\mathrm{S}_{2}\right)$ \\
\hline Tinggi $\left(\mathrm{C}_{1}\right)$ & $\mathrm{S}_{1} \mathrm{C}_{1}$ & $\mathrm{~S}_{2} \mathrm{C}_{1}$ \\
\hline Rendah $\left(\mathrm{C}_{2}\right)$ & $\mathrm{S}_{1} \mathrm{C}_{2}$ & $\mathrm{~S}_{2} \mathrm{C}_{2}$ \\
\hline
\end{tabular}

\section{Keterangan :}

$\mathrm{S}_{1} \mathrm{C}_{1}$ : Hasil belajar siswa yang diajar dengan strategi pembelajaran berorientasi aktivitas siswa pada siswa yang memiliki kemampuan berpikir kreatif tinggi

$\mathrm{S}_{1} \mathrm{C}_{2}$ : Hasil belajar siswa yang diajar dengan strategi pembelajaran berorientasi aktivitas siswa pada siswa yang memiliki kemampuan berpikir kreatif rendah

$\mathrm{S}_{2} \mathrm{C}_{1}$ : Hasil belajar siswa yang diajar dengan strategi pembelajaran ekspositori pada siswa yang memiliki kemampuan berpikir kreatif tinggi

$\mathrm{S}_{2} \mathrm{C}_{2}$ : Hasil belajar siswa yang diajar dengan strategi pembelajaran ekspositori pada siswa yang memiliki kemampuan berpikir kreatif rendah.

Teknik analisis data yang digunakan adalah teknik statistik inferensial dan deskriptif. Teknik statistik deskriptif digunakan untuk mendeskripsikan data, antara lain: nilai rata-rata (mean), median, modus, standar deviasi, dan kecenderungan data. Teknik statistik inferensial digunakan untuk menguji hipotesis penelitian, dimana teknik inferensial yang digunakan adalah teknik analisa varians (ANAVA) dua jalur dengan taraf signifikan 5\%.

Sebelum ANAVA dua jalur dilakukan terlebih dahulu diuji persyaratan analisis yakni persyaratan normalitas dan homogenitas. Untuk uji persyaratan normalitas digunakan uji Liliefors, sedang untuk uji persyaratan homogenitas digunakan uji Barlet dari Sudjana (2005:261). Jika ada interaksi antara strategi pembelajaran dengan kemampuan berpikir kreatif dalam mempengaruhi hasil belajar menggambar ekspresi maka analisis dilanjutkan menggunakan uji Scheffe karena jumlah elemen setiap sel tidak sama. Untuk pengujian hipotesis, diperlukan rumusan hipotesis statistik sebagai berikut:

Hipotesis pertama

$\mathrm{H}_{0}: \mu \mathrm{S}_{1}=\mu \mathrm{S}_{2}$

$\mathrm{H}_{\mathrm{a}}: \mu \mathrm{S}_{1}>\mu \mathrm{S}_{2}$

Hipotesis kedua

$\mathrm{H}_{\mathrm{o}}: \mu \mathrm{C}_{1}=\mu \mathrm{C}_{2}$

$\mathrm{H}_{\mathrm{a}}: \mu \mathrm{C}_{1}>\mu \mathrm{C}_{2}$

Hipotesis ketiga

$\mathrm{H}_{\mathrm{o}}: \mu \mathrm{S} \times \mu \mathrm{C}=0$

$\mathrm{H}_{\mathrm{a}}: \mu \mathrm{S} \times \mu \mathrm{C} \neq 0$ 


\section{HASIL DAN PEMBAHASAN \\ Hasil}

Dari data hasil tes kemampuan berpikir kreatif dan tes hasil belajar menggambar ekspresi didistribusikan sesuai kelompok masing-masing kemudian digabungkan, maka diperoleh data induk hasil belajar menggambar ekspresi seperti terlihat pada Tabel 4.

Tabel 4. Data Induk Hasil Belajar Menggambar Ekspresi

\begin{tabular}{|c|l|l|l|}
\hline $\begin{array}{c}\text { Strategi } \\
\text { Kemampuan }\end{array}$ & $\begin{array}{c}\text { Berorientasi } \\
\text { Aktivitas Siswa }\end{array}$ & \multicolumn{1}{|c|}{ Ekspositori } & \multicolumn{1}{c|}{ Jumlah Baris } \\
\hline Tinggi & $\mathrm{n}_{1}=15$ & $\mathrm{n}_{2}=16$ & $\overline{\mathrm{N}}_{\mathrm{c} 1}=31$ \\
& $\bar{X}_{1}=90,6$ & $\bar{X}_{2}=87,13$ & $\mathrm{~S}_{\mathrm{c} 1}=88,58$ \\
& $\mathrm{~S}_{1}=4,98$ & $\mathrm{~S}_{2}=3,65$ & $\mathrm{~S}_{\mathrm{c} 1}=4,54$ \\
\hline Rendah & $\mathrm{N}_{3}=25$ & $\mathrm{~N}_{4}=24$ & $\overline{\mathrm{N}}_{\mathrm{c} 2}=49$ \\
& $\bar{X}_{3}=75,12$ & $\bar{X}_{4}=72,33$ & $\bar{X}_{\mathrm{c} 2}=73,76$ \\
& $\mathrm{~S}_{3}=3,47$ & $\mathrm{~S}_{4}=4,99$ & $\mathrm{~S}_{\mathrm{c} 2}=4,47$ \\
\hline Jumlah Kolom & $\mathrm{N}_{\mathrm{K} 1}=40$ & $\mathrm{~N}_{\mathrm{K} 2}=40$ & $\mathrm{~N}_{\mathrm{t}}=80$ \\
& $\bar{X}_{\mathrm{K} 1}=80,75$ & $\bar{X}_{\mathrm{K} 2}=78,25$ & $\sum \mathrm{X}_{\mathrm{t}}=6360$ \\
& $\mathrm{~S}_{\mathrm{K} 1}=8,40$ & $\mathrm{~S}_{\mathrm{K} 2}=8,58$ & $\sum \mathrm{X}_{\mathrm{t}}=511368$ \\
\hline
\end{tabular}

Berdasarkan perhitungan ANAVA faktorial 2 x 2 diperoleh ringkasan hasil ANAVA

Tabel.20 Ringkasan Hasil ANAVA Faktorial 2 x 2 Hasil Belajar Menggambar Ekspresi

\begin{tabular}{|l|l|l|l|l|l|}
\hline \multicolumn{1}{|c|}{ Sumber Variasi } & \multicolumn{1}{c|}{$\mathrm{dk}$} & \multicolumn{1}{c|}{ JK } & \multicolumn{1}{c|}{ RJK } & \multicolumn{1}{c|}{ F $_{\text {hitung }}$} & \multicolumn{1}{c|}{$\begin{array}{c}\mathrm{F}_{\text {tabel }} \\
\alpha=0,05\end{array}$} \\
\hline Strategi Pembelajaran (antar kolom) & 1 & 125 & 125 & 6,740 & 3,97 \\
\hline $\begin{array}{l}\text { Kemampuan Berpikir Kreatif Siswa } \\
\text { (antar baris) }\end{array}$ & 1 & 4173,39 & 4173,39 & 225,041 & 3,97 \\
\hline Interaksi & 1 & 40,31 & 40,31 & 2,174 & 3,97 \\
\hline Galat & 76 & 1409,457 & 18,545 & & \\
\hline
\end{tabular}

\section{Pembahasan}

Dalam penelitian ini materi menggambar ekspresi yang diberi perlakuan terdiri dari fakta, konsep, prinsip dan prosedur. Untuk itu diperlukan keterlibatan siswa secara aktif baik fisik maupun mental untuk mengolah, meresktrukturisasi seluruh konsep dalam mencapai tujuan pembelajaran yang diharapkan. Penerapan strategi pembelajaran berorientasi aktivitas siswa yaitu dengan mengarahkan siswa kepada rangkaian kegiatan pembelajaran yang menekankan aktivitas siswa secara optimal untuk memperoleh hasil belajar berupa perpaduan antara aspek kognitif, afektif, dan psikomotor secara seimbang dan terpadu. Tujuan strategi pembelajaran berorientasi aktivitas siswa adalah untuk membantu peserta didik agar dapat belajar mandiri dan kreatif, sehingga ia dapat memperoleh pengetahuan, keterampilan, dan sikap yang dapat menunjang terbentuknya kepribadian yang mandiri.
Sedangkan strategi pembelajaran ekspositori adalah strategi yang berpusat pada guru yang bercirikan siswa menerima informasi secara pasif, perilaku dibangun atau kebiasaan keterampilan dikembangkan atas dasar latihan dan pengetahuan adalah penangkapan terhadap serangkaian fakta, konsep atau hukum yang berada diluar diri siswa.

Berdasarkan hasil pengujian hipotesis pertama diperoleh temuan bahwa, hasil belajar menggambar ekspresi siswa yang diajar dengan strategi pembelajaran berorientasi aktivitas siswa lebih tinggi dari pada hasil belajar menggambar ekspresi siswa yang diajar dengan strategi pembelajaran ekspositori. Dengan demikian dapat dinyatakan penggunaan strategi pembelajaran berorientasi aktivitas siswa memberikan pengaruh yang signifikan terhadap hasil menggambar ekspresi siswa, karena hasil pengamatan menunjukkan ketika pelaksanaan proses pembelajaran dengan strategi 
pembelajaran berorientasi aktivitas siswa, pengelompokkan siswa direncanakan dengan matang dan dikondisikan. Sedangkan dengan strategi pembelajaran ekspositori pengelompokan terjadi secara spontan dan terdiri dari keseluruhan siswa. Keadaan ini jelas mempengaruhi hasil belajar menggambar ekspresi, karena pada kelompok strategi pembelajaran berorientasi aktivitas siswa lebih leluasa untuk belajar mandiri dan kreatif, sehingga ia dapat memperoleh keterampilan yang dapat menunjang terbentuknya kepribadian yang mandiri.

Berikutnya dalam strategi pembelajaran ekspositori, pembelajaran berpusat pada guru, siswa kurang diberdayakan dan komunikasi yang terjadi umumnya bersifat satu arah. Dalam proses pembelajaran ekspositori siswa hanya dapat menyelesaikan masalah sesuai dengan cara yang ditunjukkan guru, sehingga membuat siswa bersifat menunggu penjelasan dari guru, atau guru mengajarkan materi tertuju pada pembelajaran saja, siswa kurang berani bertanya atau memberi tanggapannya terhadap masalah dalam pembelajaran tersebut.

Peranan guru dalam strategi pembelajaran ekspositori adalah sebagai pembimbing program, memberikan penjelasan kepada siswa dan diiringi dengan memberi tugas dan latihan. Para siswa memperoleh sejumlah pengetahuan yang diterima dari guru, sedang mereka sendiri tidak dibiasakan untuk mencoba menemukan pengetahuan informasi, siswa menerima pembelajaran secara pasif. Bentuk kegiatan pembelajaran ini berlangsung dengan menggunakan guru sebagai satu-satunya sumber belajar sakaligus bertindak sebagai penyaji isi pelajaran. Siswa mengikuti kegiatan pembelajaran tersebut dengan cara mendengarkan ceramah dari guru, mencatat dan mengerjakan tugas-tugas yang diberikan oleh guru.

Selanjutnya sesuai dengan hasil penelitian Kartimi (2008) dalam strategi pembelajaran berorientasi aktivitas siswa menemukan, siswa merasa senang dengan situasi belajarnya, terlibat aktif dan mandiri dalam mengemukakan gagasan, pendapat, dan menyampaikan argumentasinya. Sehingga memperoleh kesimpulan strategi pembelajaran berorientasi aktivitas siswa dapat meningkatkan penguasaan konsep dan berpikir kreatif siswa.

Kemudian hasil pengujian hipotesis kedua diperoleh, siswa yang memiliki kemampuan berpikir kreatif tinggi memperoleh hasil belajar menggambar ekspresi lebih tinggi dari siswa yang memiliki kemampuan berpikir kreatif rendah. Dari karakteristik siswa yang memiliki kemampuan berpikir kreatif tinggi siswa cenderung lebih aktif. siswa dengan kemampuan berpikir kreatif tinggi yaitu terbuka terhadap pengalaman baru, luwes terhadap pengalaman baru, luwes dalam berpikir dan bertindak, bebas dalam mengekspresikan diri, dapat mengekspresikan fantasi, berminat pada kegiatan kreatif, percaya pada gagasan sendiri, mampu memahami, mengklasifikasi, mengaplikasikan aturan atau prinsip dalam sebuah pola atau urutan bentuk gambar, dan mengidentifikasi hubungan dalam satu pasangan gambar.

Siswa dengan kemampuan berpikir kreatif tinggi umumnya senang dengan pembelajaran menggambar ekspresi karena mereka cenderung memiliki rasa ingin tahu yang lebih besar dan tertantang melakukan berbagai praktik menggambar untuk secara langsung terlibat dalam berbagai pengalaman belajar. Mereka memiliki daya imajinasi yang tinggi untuk mengkonstruksi gambar menjadi lebih mudah untuk dipahami. Berbagai keterbatasan dalam proses belajarnya bukan hambatan bagi dirinya untuk mengeksplorasi pengetahuan dengan lebih mandiri dalam belajar, serta komitmen tinggi untuk mencapai cara-caranya sendiri.

Berbeda dengan siswa dengan kemampuan berpikir kreatif tinggi, siswa yang memiliki kemampuan berpikir kreatif rendah justru sebaliknya, mereka tidak terbuka terhadap pengalaman baru dan cenderung menutup diri dan tidak suka menerima tantangan, kaku dalam berpikir dan bertindak, tidak berani mengekspresikan diri dan cenderung ikut-ikutan, kurang mandiri dan tidak percaya diri dengan gagasan sendiri. Hal ini dapat dilihat dari ketidakmampuan memahami, mengklasifikasi, mengaplikasikan, mengidentifikasi aturan atau prinsip dalam sebuah pola atau urutan bentuk gambar.

Siswa dengan kemampuan berpikir kreatif rendah tidak memiliki daya imajinasi yang cukup memadai untuk mengkonstruksi gambar, sehingga lebih sulit dalam memahami pelajaran. Selain itu karena tidak suka dengan tantangan dan cenderung tidak percaya diri, mereka cenderung tidak suka terlibat secara aktif dalam kegiatan pembelajaran kelas. Pernyataan ini sesuai dengan hasil penelitian Mulyadi (2007) tentang hubungan antara kemampuan berpikir kreatif dan inteligensi dengan prestasi akademik pada Sekolah Dasar 
Mutiara Indonesia, menemukan bahwa siswa yang berhasil dalam bidang akademik cenderung dianggap siswa yang kreatif, cerdas atau mempunyai tingkat inteligensi yang tinggi. Penelitian ini menunjukkan ada hubungan positif antara kemampuan berpikir kreatif dan inteligensi dengan prestasi akademik. Sehingga diperoleh kesimpulan bahwa semakin tinggi kemampuan berpikir kreatif dan inteligensi siswa, maka semakin tinggi prestasi akademiknya.

Selanjutnya hasil pengujian hipotesis ketiga, tidak terdapat interaksi antara strategi pembelajaran dan kemampuan berpikir kreatif siswa dalam memberikan pengaruh terhadap hasil belajar menggambar ekspresi karena $F_{\text {hitung }}<\mathrm{F}_{\text {tabel }}=3,97$. Hal ini disebabkan siswa yang memiliki kemampuan berpikir kreatif tinggi kurang tepat bila diajar dengan strategi pembelajaran ekspositori, dengan kata lain bila siswa yang memiliki kemampuan berpikir kreatif tinggi diajar dengan strategi pembelajaran ekspositori akan menimbulkan kebosanan, sehingga situasi belajar siswa tidak sesuai atau siswa kurang bebas mengembangkan kreatifitas belajarnya. Dalam praktik menggambar ekspresi siswa kurang aktif karena dibatasi oleh keaktifan guru, dengan demikian siswa bersifat pasif dan terikat dengan penjelasan guru atau penjelasan siswa tentang masalah cenderung sesuai dengan penjelasan guru. Pada akhirnya membuat kemampuan berpikir kreatif siswa tidak dapat berkembang secara optimal. Strategi pembelajaran ekspositori cenderung dilaksanakan secara klasikal, jadi sudah wajar bila siswa yang memiliki kemampuan berpikir kreatif tinggi memperoleh hasil belajar menggambar ekspresi lebih tinggi yang diajar dengan strategi pembelajaran berorientasi aktivitas siswa dibanding dengan strategi pembelajaran ekspositori. Temuan ini sesuai dengan hasil penelitian Linda (2009) mengenai pengaruh strategi pembelajaran berorientasi aktivitas siswa dan adopsi informasi terhadap hasil belajar siswa SMP Negeri 3 Bahorok. Hasil penelitian ini diperoleh bahwa hasil belajar biologi antara siswa yang diajar dengan strategi pembelajaran berorientasi aktivitas siswa dan strategi pembelajaran konvensional, dimana nilai rata-rata biologi siswa yang diajar dengan strategi pembelajaran berorientasi aktivitas siswa lebih tinggi dibandingkan dengan siswa yang diajar dengan strategi pembelajaran konvensional.
Dari skor rata-rata antara perlakuan yang menunjukkan bahwa siswa yang memiliki kemampuan berpikir kreatif tinggi yang diajar dengan strategi pembelajaran berorientasi aktivitas siswa lebih tinggi dari pada yang diajar dengan strategi pembelajaran ekspositori, sebaliknya siswa yang memiliki kemampuan berpikir kreatif rendah yang diajar dengan strategi pembelajaran ekspositori memperoleh skor rata-rata lebih tinggi dari siswa yang diajar dengan strategi pembelajaran berorientasi aktivitas siswa. Hasil ini menunjukkan bahwa strategi pembelajaran berorientasi aktivitas siswa lebih sesuai digunakan untuk mengajar siswa yang memiliki kemampuan berpikir kreatif tinggi sedangkan strategi pembelajaran ekspositori lebih sesuai digunakan untuk mengajar siswa yang memiliki kemampuan berpikir kreatif rendah.

Strategi pembelajaran berorientasi aktivitas siswa yang menekankan keaktifan dan kemandirian siswa dalam belajar sesuai dengan karakteristiknya, memiliki kemampuan berpikir kreatif tinggi akan benar-benar terlibat dalam kegiatan pembelajaran dan memberi kesempatan kepada siswa untuk mengembangkan konsep berkarya visual yang lebih baik. Sedangkan strategi pembelajaran ekspositori yang menekankan keaktifan guru dalam menjelaskan materi pembelajaran, sesuai dengan karakteristik siswa yang memiliki kemampuan berpikir kreatif rendah, tidak begitu aktif cara belajarnya, sehingga materi pembelajaran menggambar ekspresi hendaknya dijelaskan guru agar siswa dapat memahami pelajaran yang diperolehnya. Kelebihan strategi pembelajaran berorientasi aktivitas siswa bila digunakan untuk mengajar siswa yang memiliki kemampuan berpikir kreatif tinggi dan sebaliknya kelebihan strategi pembelajaran ekspositori bila digunakan untuk mengajar siswa yang memiliki kemampuan berpikir kreatif rendah, secara konsisten menunjukkan adanya interaksi antara strategi pembelajaran dan kemampuan berpikir kreatif siswa dalam mempengaruhi hasil belajar menggambar ekspresi.

\section{PENUTUP \\ Simpulan}

Siswa yang diajar dengan strategi pembelajaran berorientasi aktivitas siswa memperoleh hasil belajar menggambar ekspresi lebih tinggi dari siswa yang diajar dengan menggunakan strategi pembelajaran ekspositori; 
Siswa yang memiliki kemampuan berpikir kreatif tinggi memperoleh hasil belajar menggambar ekspresi lebih tinggi dari siswa yang memiliki kemampuan berpikir kreatif rendah. Siswa yang memiliki kemampuan berpikir kreatif tinggi siswa cenderung lebih aktif, siswa dengan kemampuan berpikir kreatif tinggi yaitu terbuka terhadap pengalaman baru, luwes terhadap pengalaman baru, luwes dalam berpikir dan bertindak, bebas dalam mengekspresikan diri, dapat mengekspresikan fantasi, berminat pada kegiatan kreatif, percaya pada gagasan sendiri, mampu memahami, mengklasifikasi, mengaplikasikan aturan atau prinsip dalam sebuah pola atau urutan bentuk gambar, dan mengidentifikasi hubungan dalam satu pasangan gambar.

Terdapat interaksi antara strategi pembelajaran dengan kemampuan berpikir kreatif siswa dalam mempengaruhi hasil belajar menggambar ekspresi siswa; (a) Hasil belajar menggambar ekspresi kelompok siswa yang memiliki kemampuan berpikir kreatif tinggi, siswa yang diajar dengan strategi pembelajaran berorientasi aktivitas siswa lebih tinggi dari hasil belajar menggambar ekspresi siswa yang diajar dengan strategi pembelajaran ekspositori. Dengan demikian penggunaan strategi pembelajaran berorientasi aktivitas siswa lebih tepat bagi siswa yang memiliki kemampuan berpikir kreatif tinggi dibandingkan dengan penggunaan strategi pembelajaran ekspositori; dan (b) Hasil belajar menggambar ekspresi kelompok siswa yang memiliki kemampuan berpikir kreatif rendah, siswa yang diajar dengan strategi pembelajaran ekspositori lebih tinggi dari hasil belajar menggambar ekspresi siswa yang diajar dengan strategi pembelajaran berorientasi aktivitas siswa. Dengan demikian strategi pembelajaran ekspositori lebih tepat digunakan bagi siswa yang memiliki kemampuan berpikir kreatif rendah dibandingkan dengan strategi pembelajaran berorientasi aktivitas siswa.

\section{Saran}

Penelitian ini masih perlu dikembangkan lebih lanjut yang lebih luas, disarankan pada peneliti yang lain untuk melakukan penelitian di daerah lain dengan situasi dan kondisi yang berbeda sehingga diperoleh hasil penelitian yang dapat mencerminkan kondisi yang lebih umum.

Dilakukan dengan sosialisasi strategi kepada guru-guru kemudian menerapkan strategi pembelajaran yang sesuai antara lain adalah strategi pembelajaran berorientasi aktivitas siswa dan strategi pembelajaran ekspositori.

Guru sebagai perancang pembelajaran perlu mempertimbangkan kemampuan berpikir kreatif siswa dalam merancang proses pembelajaran. Strategi pembelajaran berorientasi aktivitas siswa lebih tepat diterapkan pada siswa yang memiliki kemampuan berpikir kreatif tinggi dan strategi pembelajaran ekspositori lebih tepat diterapkan pada siswa yang memiliki kemampuan berpikir kreatif rendah.

\section{DAFTAR PUSTAKA}

Anastasi, A. 2007. Psychological Testing. New Jersey: Prentice Hall.

Arikunto, S. 2005a. Dasar-Dasar Evaluasi Pendidikan. Jakarta: Bumi Aksara.

-------. 2005b. Prosedur Penelitian Suatu Pendekatan Praktik. Jakarta: Rineka Cipta.

Ayan, J. 2002. Bengkel Kreativitas. Bandung: Kaifa.

Depdiknas RI. 2006. Kurikulum Tingkat Satuan Pendidikan (KTSP). Jakarta: Puskur.

Dick, W. \& Carey, L. 2005. The Systematic Design of Instruction. Boston, New York, San Fransisco: Pearson.

Dimyati dan Mudjiono. 2009. Belajar dan Pembelajaran. Jakarta: Rineka Cipta.

Gagne, R. \& Briggs, L. 1979. Principles of Instructional Design. New York: Holt, Rinehart and Winston.

Hamalik, O. 2008a. Perencanaan Pengajaran: berdasarkan Pendekatan Sistem. Jakarta: Bumi Aksara.

--------. 2008b. Proses Belajar-Mengajar. Jakarta: Bumi Aksara.

Kemp, J. \& Morisson, G. 2001. Designing Effective Instruction. United States of America: John Wiley \& Sons. Inc.

Mesra. 2005. Ungkapan Kreativitas Seni Dalam Karya Keramik, Jurnal Seni Rupa FBS UNIMED, 2 (1): 27-36.

Miarso, Y. 2007. Menyemai Benih Teknologi Pendidikin. Jakarta: Kencana.

Muharram. 1992. Pendidikan Kesenian Seni Rupa. Jakarta: P\& K.

Munandar, U. 2009. Pengembangan Kreativitas Anak Berbakat . Jakarta: Rineka Cipta.

Nursantara, Y. 2004a. Kesenian SMA: untuk Kelas $X$. Jakarta: Erlangga. ----. 2004b. Kesenian SMA: untuk Kelas $X I$. Jakarta: Erlangga. 
2004c. Kesenian SMA: untuk Kelas XII. Jakarta: Erlangga

---------. 2007. Seni Budaya: untuk SMA Kelas XI. Jakarta: Erlangga.

Nursisto. 2000. Menggali Kreativitas. Jakarta: Mitra Gama Widya.

Roestiyah. 2008. Strategi Belajar Mengajar. Jakarta: Rineka Cipta.

Sabana, S. \& Saidi, A. 2007. Seni Rupa: untuk SMA dan MA Kelas XI. Jakarta: Erlangga.

Sachari, A. 2007a. Seni Rupa dan Desain: untuk SMA Kelas X. Bandung: Erlangga.

--------. 2007b. Seni Rupa dan Desain: untuk SMA Kelas XI. Bandung: Erlangga.

--------. 2007c. Seni Rupa dan Desain: untuk SMA Kelas XII. Bandung: Erlangga.

Sagala, H. Sy. 2007. Konsep dan Makna Pembelajaran. Bandung: Alfabeta

Slameto. 2010. Belajar dan Faktor-Faktor yang Mempengaruhinya. Jakarta: Rineka Cipta.

Sanjaya, W. 2010. Strategi Pembelajaran Berorientasi Standar Proses Pendidikan. Jakarta: Kencana.

Semiawan, C. 1997a. Perspektif Pendidikan Anak Berbakat. Jakarta. Gramedia. 2009b. Kreativitas Keberbakatan: mengapa, apa, dan bagaimana. Jakarta: Indeks.

Soesatyo. 1992. Rancangan Kegiatan Pendidikan Kesenian II. Yogyakarta: P \& $\mathrm{K}$.

Sudijono, A. 2009. Pengantar Evaluasi Pendidikan. Jakarta: Rajawali Pers

Sudjana. 2005a. Metoda Statistika. Bandung. Tarsito.

-2 2005b. Teknik Analisis Regresi dan Korelasi. Bandung: Tarsito.

Suparman, A. 2001. Desain Instruksional. Jakarta: PAU-PPAI-UT.

Tim Pascasarjana UNIMED, 2010. Pedoman Administrasi dan Penulisan Tesis \& Desertasi. Medan: Pascasarjana UNIMED

Trianto. 2010. Mendesain Model Pembelajaran Inovatif-Progresif: Konsep, Landasan, dan Implementasinya Pada KTSP.Jakarta: Kencana.

Usman, H \& Akbar, S. 2009. Pengantar Statistika. Jakarta: Bumi Aksara.

Widya, G. 2010. Seni Budaya dan Keterampilan: Untuk SMA/MA Kelas XI. Bandung. Yrama. 